\title{
Recent advances in the effects of microwave radiation on brains
}

\author{
Wei-Jia Zhi, Li-Feng Wang ${ }^{*}$ and Xiang-Jun Hu*
}

\begin{abstract}
This study concerns the effects of microwave on health because they pervade diverse fields of our lives. The brain has been recognized as one of the organs that is most vulnerable to microwave radiation. Therefore, in this article, we reviewed recent studies that have explored the effects of microwave radiation on the brain, especially the hippocampus, including analyses of epidemiology, morphology, electroencephalograms, learning and memory abilities and the mechanisms underlying brain dysfunction. However, the problem with these studies is that different parameters, such as the frequency, modulation, and power density of the radiation and the irradiation time, were used to evaluate microwave radiation between studies. As a result, the existing data exhibit poor reproducibility and comparability. To determine the specific dose-effect relationship between microwave radiation and its biological effects, more intensive studies must be performed.
\end{abstract}

Keywords: Microwave, Central nervous system, Dysfunction of learning and memory abilities

\section{Background}

Microwaves are electromagnetic waves with frequencies ranging from $300 \mathrm{MHz}$ to $300 \mathrm{GHz}$. Microwaves are widely used in households, industry, communications, and medical and military buildings, and they provide substantial contributions to the development of human society. However, with its popularization, increasing attention has been paid to its influence on humans. Electromagnetic radiation can be absorbed by organisms, in which it causes a series of physiological and functional changes. Many intricate electrical activities occur in the central nervous system, including learning and memory, which are therefore vulnerable to electromagnetic radiation. Moreover, the popularization of mobile phones has made them the main source of brain exposure to radiation. Therefore, the central nervous system is considered one of the most sensitive organs that is targeted by microwave radiation $[1,2]$. A large number of studies have shown that microwave radiation can cause a series of adverse reactions in the central nervous system, including sleep disorders in addition to learning and memory impairments.

\footnotetext{
*Correspondence: fangchang_14@163.com; xjhu2003@vip.sina.com Laboratory of Experimental Pathology, Beijing Institute of Radiation Medicine, Beijing 100850, China
}

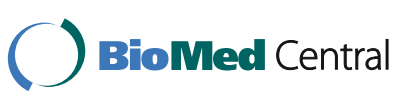

(c) The Author(s). 2017 Open Access This article is distributed under the terms of the Creative Commons Attribution 4.0 International License (http://creativecommons.org/licenses/by/4.0/), which permits unrestricted use, distribution, and reproduction in any medium, provided you give appropriate credit to the original author(s) and the source, provide a link to the Creative Commons license, and indicate if changes were made. The Creative Commons Public Domain Dedication waiver (http://creativecommons.org/publicdomain/zero/1.0/) applies to the data made available in this article, unless otherwise stated.
Microwaves are widely used in broadcasting, commusources of microwaves are mainly FM radio and TV broadcasting antennas, which produce frequencies ranging from 80 to $800 \mathrm{MHz}$. In communications, the microwaves come from mobile phones and their base stations and microwave links, in addition to cordless phones, terrestrial trunked radios, blue tooth devices, wireless local area networks and many other applications. The frequencies of these devices are listed in Table 1. In industrial fields, exposure is usually occupational, and its sources include the surgical and physiotherapeutic use of diathermy, dielectric heating (i.e., heating and vulcanization applications), microwave ovens, magnetic resonance imaging (MRI) medical diagnostic equipment, radar, military and research microwave systems, electricity-supplying networks, and electricity-distributing and transmitting equipment [3].

Based on this background, in this review, we first summarized the effects of microwave radiation on the central nervous system, including the epidemiology, morphology, electroencephalograms, learning and memory abilities and mechanisms of underlying brain dysfunction from the perspective of synaptic structures and functions, oxidative stress and apoptosis, protein synthesis, genes and individual susceptibility and energy metabolism. 
Table 1 Source and frequency range of microwave

\begin{tabular}{ll}
\hline Application & Frequency range $(\mathrm{MHz})$ \\
\hline FM radio and TV broadcasting antennas & $80-800$ \\
Mobile phones & $453.5-1980.0$ \\
Mobile phone base station & $463.5-2170.0$ \\
Microwave links & 1000 \\
Cordless phones & $1880-1900$ \\
Terrestrial trunked radio & $380-470$ \\
Bluetooth devices & 2450 \\
Baby monitors & $40,446,864,1900$ and 2450 \\
Wireless local area networks & 2400 and 5000 \\
Smart meters & $900-1900$ or 2400 \\
Surgical and physiotherapeutic & 2450 \\
Diathermy & 2450 and 434 \\
Microwave ovens & $915-2450$ \\
Radar & $30-300,000$ \\
\hline
\end{tabular}

\section{Epidemiology}

In 2011, the International Agency for Research on Cancer (IARC) announced that microwave radiation has potentially carcinogenic effects (2B). However, it concurrently also declared that the carcinogenic potential of mobile communications equipment was limited to glioma [4].

\section{Exposure to mobile phones}

Of the numerous studies performed to explore the effects of mobile communication devices on humans, only a few have shown that cell phones and brain tumors are statistically correlated. For example, people who have used mobile phones for more than 10 years have a clearly higher risk of brain tumors. Those who are accustomed to using their mobile phone ipsilaterally presented a probability that was twice that of people who don't [5-7]. However, most studies have not supported the conclusion that cell phones cause brain tumors [8-12]. One study reported by the Interphone study group [13] showed that there was no increase in the risk of glioma or meningioma in users of mobile phones. It has been suggested that there is an increased risk of glioma at the highest exposure levels, but biases and errors prevent causal interpretations of these data. Additionally, Larjabaara et al. [14] found that gliomas are not preferentially located in the parts of the brain with the highest exposure. Finally, Hardell et al. [15] assessed the use of mobile and cordless phones in 347 cases of melanoma in the head and neck region and 1184 controls and found no increased risk.

\section{Occupational exposure Industrial exposure}

In long-term epidemiological investigations of large population with occupational exposure, the results have not been consistent. Dasdag et al. [16] investigated workers who worked at a television transmitter station with a frequency ranging between 202 and $209 \mathrm{MHz}$, 694$701 \mathrm{MHz}, 750-757 \mathrm{MHz}$, or $774-781 \mathrm{MHz}$ and at a medium-wave broadcasting station. Their answers to questionnaires showed that the workers suffered from symptoms including headaches, fatigue, stress and sleeplessness. Most of the workers recovered when they left the source of microwave radiation. In addition, another study showed that significant psychiatric symptoms were observed in people who worked in these areas. In particular, somatization, obsessive compulsivity, paranoid ideation and psychoticism were reported [17].

\section{Military exposure}

Standard devices used by military personnel that may pose electromagnetic hazards include radars and missile systems. In a report by the Poland Department of Microwave Safety, occupational exposure to electromagnetic fields was analyzed in the work environment of personnel of 204 devices divided into 5 groups (surfaceto-air missile system radars, aircraft and helicopters, communication devices, surveillance and height finder radars, airport radars and radio navigation systems). In $57 \%$ of military devices, Polish soldiers work in occupational protection zones. In 35\% of cases, soldiers work in intermediate and hazardous zones and in $22 \%$-only in the intermediate zone. In $43 \%$ of devices, military personnel are not exposed to an electromagnetic field.

The visual reaction time and short-term memory of healthy male and female workers at a radar site with a frequency range of $2-18 \mathrm{GHz}$ was recorded with a simple blind computer-assisted-visual reaction time test or modified Wechsler Memory Scale test. The results indicated that radar microwave radiation leads to a decreased reaction time and lower short-term memory performance [18]. Among radar workers exposed to 14$18 \mathrm{GHz}$ microwaves, the somatic symposium anxiety and insomnia, social dysfunction and severe depression were caused [19]. Singh et al. [20] divided the radar workers into three sets: control group $(n=68)$, exposure group I ( $n=40$, exposed to 8-12 $\mathrm{GHz}$ ) and exposure group II ( $n=58$, working with radar at $12.5-18.0 \mathrm{GHz})$. The three groups were further divided into two groups according to their years of service (up to 10 years and $>10$ years) to investigate the effect of years of exposure to radar. Melatonin and serotonin levels were estimated, which play important roles in the nervous system. The results demonstrated the ability of electric magnetic field (EMF) to influence plasma melatonin and serotonin concentrations in radar workers. The results were significant for the range from $12.5-18.0 \mathrm{GHz}$ with a service period greater than 10 years. Additionally, people exposed to military microwave sources were more 
vulnerable to brain tumors. Richter et al. [21, 22] found a higher incidence of brain cancer in radar technicians and a shortened incubation period (i.e., less than 10 years). Szmigielski [23] collected retrospective data for Polish soldiers over 15 years and showed that the prevalence of brain cancer was higher in each age group.

\section{Effects of microwave radiation on children}

Because a child's nervous system is growing and their head is more vulnerable to radiation energy, studies that have specifically addressed whether the nervous systems of children are more susceptible to electromagnetic radiation have been performed. However, there is little scientific evidence to demonstrate that children are more sensitive to electromagnetic radiation than adults $[24,25]$.

\section{Positive effects}

With the increasing number of applications that use microwave technology, its negative effects on the human body have attracted attention. However, its beneficial effects should not be ignored [26]. For example, it can shorten reaction times so that people can better cope with danger. Mortazavi et al. [27] found that college students' visual reaction times were significantly shorter after $10 \mathrm{~min}$ of phone-induced microwave radiation. This conclusion is consistent with the results of a previously reported study that showed that short-term exposure to microwave radiation can reduce reaction times and improve cognitive functions, attention and shortterm memory capacity [28-34]. Moreover, the risk of developing Alzheimer's disease is $30-40 \%$ lower in people who use a mobile phone for more than 10 years than in other individuals [35]. The above results indicate a positive biological effect of microwave radiation and present a challenge with regard to how people can benefit from microwave radiation.

Above all, because of biases and variations in investigation methods, no conclusive evidence has been presented that microwaves cause cancer. We should ensure that we avoid excessive exposure to microwave radiation in daily life activities and use mobile phones appropriately despite information about its positive effects. In the population with occupational exposure, proper protective measures should be taken to avoid unnecessary harm. These conclusions are presented in Table 2.

\section{The influence of microwave radiation on the central nervous system Negative effects}

A popular focus among researchers is the damage that microwave radiation causes in the central nervous system, in which it can impair learning and memory.

The Morris water maze has been widely used in neurobehavioral tests [36]. This classical method is often used to test learning and memory abilities after exposure to microwave radiation. Sareesh et al. [37] exposed male Wistar rats (10-12 weeks old) to a Global System for Mobile Communication (GSM) $(900 / 1800 \mathrm{MHz})$ mobile phone that was in vibrating mode (i.e., no ring tone). In the treated rats, 50 calls were missed each day for 4 weeks, and the spatial memory abilities of the rats were tested after the experimental period. They found that escape times were substantially decreased when the animals were trained while exposed to the phone. In the probe test, the exposed group could not locate the platform and exhibited a significantly higher mean latency (i.e., 3-fold higher) to reach the target quadrant, and they spent only half the time that the controls spent in the target quadrant. These results indicated that mobile phone exposure affected the acquisition of learned responses in Wistar rats. Wang et al. [38] exposed Wistar rats to a $2.856 \mathrm{GHz}$ pulsed microwave field for $6 \mathrm{~min}$. The fields had an average power density of $0,5,10$ or $50 \mathrm{~mW} / \mathrm{cm}^{2}$. The results showed that at $6 \mathrm{~h}, 1 \mathrm{~d}$ and $3 \mathrm{~d}$ after exposure, the groups in which the average power density was $10 \mathrm{~mW} / \mathrm{cm}^{2}$ or $50 \mathrm{~mW} / \mathrm{cm}^{2}$ displayed significant deficits in spatial learning and memory. Additionally, the number of crossings was significantly lower at $3 \mathrm{~d}$ after microwave radiation.

\section{Neutral effects}

Researchers have also used the 12-arm maze test on rats to test spatial working ability after exposure to $2.45 \mathrm{GHz}$ pulse microwave radiation. Lai et al. [39] exposed rats to microwaves (500 pps, pulse width $=2 \mu \mathrm{s}$, and average whole body-specific absorption rate $(\mathrm{SAR})=0.6 \mathrm{~W} / \mathrm{kg}$ ) for an exposure duration of $45 \mathrm{~min}$, and a significant decline was observed in the rats' performance, indicating that microwave radiation influenced their working memory. However, these experimental results remain to be supported in repeated experiments [40-42]. Cassel et al. [41] exposed rats to $2.45 \mathrm{GHz}$ microwaves $(2 \mu$ pulse width, $500 \mathrm{pps}$, and SAR $0.6 \mathrm{~W} / \mathrm{kg}$ ) for $45 \mathrm{~min}$ and found that microwave-induced behavioral alterations measured by Lai had more to do with factors related to performance bias than to spatial working memory. Cosquer et al. [40] also repeated the experiment only and found that radial-arm maze performance in rats remained unchanged. Cobb et al. [42] found similar results. Thus, Cosquer et al. [40] concluded that despite the differences in the conditions used in the experiments, space limitations and whether the wall of the maze was clear did not substantially influence outcomes.

Positive results were obtained in Morris water maze tests that demonstrated that microwaves influenced learning and memory in rats. However, these effects were not observed in radial arm maze tests. One reason for this difference may be that the water maze 


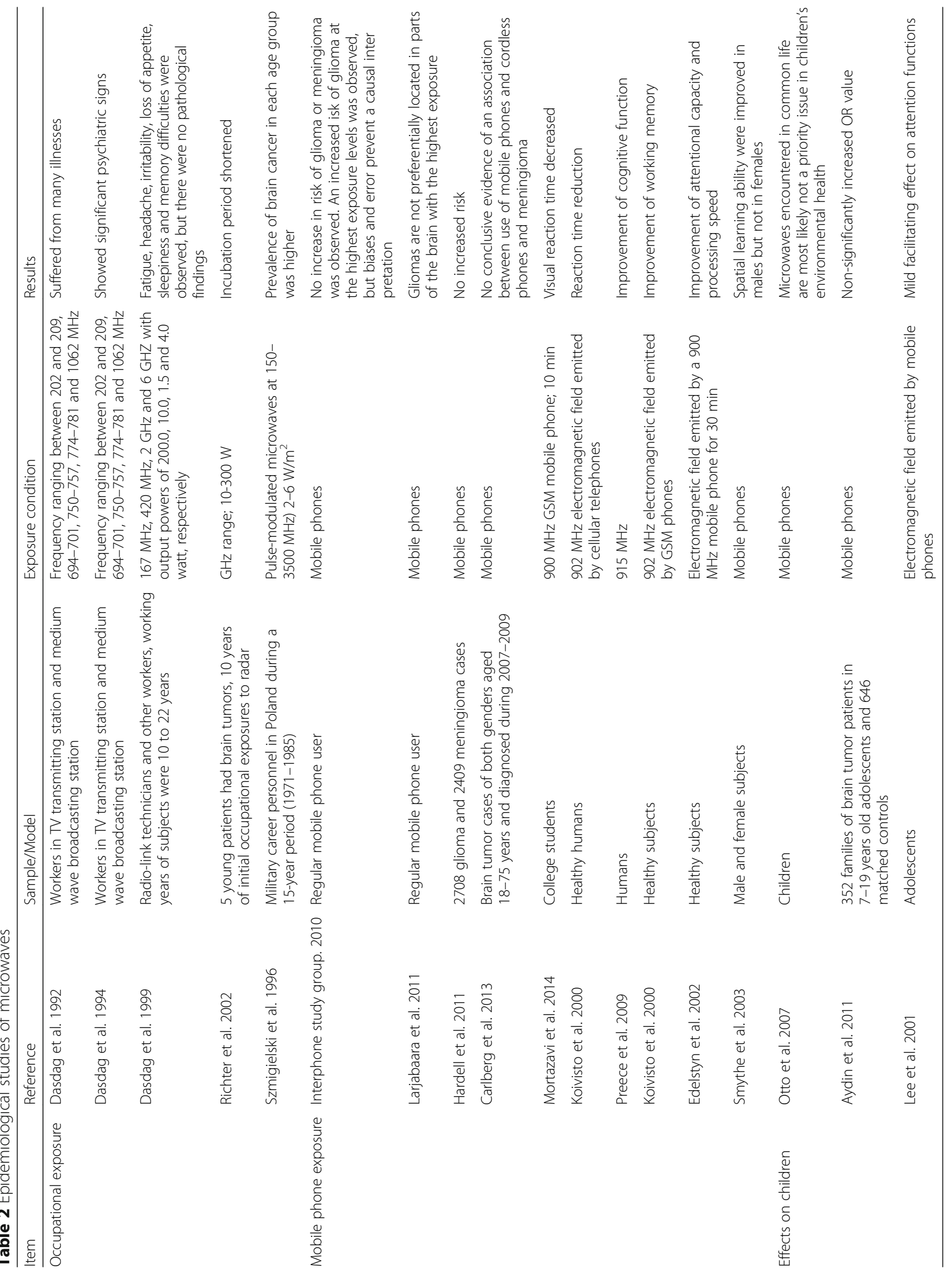


experiment is driven by aversion, whereas the arm maze experiment is driven by appetite. The former is now recognized worldwide as a method for evaluating learning and memory, while the latter is viewed as more susceptible to other factors. The conclusions are shown in Table 3.

\section{The influence of microwave radiation on the morphology of the brain}

The central nervous system, especially the hippocampus, is highly sensitive to microwave radiation [43, 44]. Previous studies have shown that in unexposed control rats, hippocampal neurons are aligned in neat rows in which the edges are clear, nuclei are clear, nucleoli can be observed, and pyramidal cells do not exhibit obvious necrosis. However, in rats treated with long-term exposure to radiation, neurons exhibit edema and are arranged irregularly. Nuclear pyknosis and capillary congestion are also observed.

Regarding the ultra-structure of the hippocampus, symptoms including neuronal atrophy, mitochondrial swelling, crest reduction and a disordered arrangement were observed, the rough endoplasmic reticulum exhibited cystic expansion, the number of synaptic vesicles decreased, and the synaptic cleft was widened $(2.45 \mathrm{GHz}$ pulsed microwave field at an average power density of $1 \mathrm{~mW} / \mathrm{cm}^{2}$ for $3 \mathrm{~h} / \mathrm{d}$ for up to 30 days [45] and an average power density of $2.5,5$, or $10 \mathrm{~mW} / \mathrm{cm}^{2}$ for $6 \mathrm{~min} / \mathrm{d}$ for up to 1 month resulted in an average calculated SAR of $1.05,2.1$, and $4.2 \mathrm{~W} / \mathrm{kg}$, respectively [46]). The hippocampus plays roles in learning and memory, and the results of these studies suggest that the deficits in learning and memory functions observed after exposure to microwave irradiation might be due to abnormalities induced in hippocampal structures.

\section{The influence of microwave radiation on electroencephalograph (EEG) data}

Brain electrical activity originates from the membrane potential of the neuron itself and the fluctuation in membrane potential. The transduction of a nerve impulse and the postsynaptic potential produced by it result in synaptic transmission. EEG data reflect the functional state of the brain by enlarging the autologous weak bioelectricity recorded by the EEG-recording instrument [47]. An abnormal EEG is closely associated with damaged cognitive ability. EEG is often used as a tool to diagnose Alzheimer's disease [48]. Most studies have suggested that microwave radiation can cause EEG abnormalities in experimental animals and participants, but some negative results have also been reported in studies using low-power microwaves.

Vorobyov et al. [1] used 10 freely moving rats in which carbon electrodes were implanted in the cortex and dorsomedial hypothalamus. Of these, five rats were repeatedly exposed to extremely low-frequency microwaves (915 MHz; pulse width, $20 \mathrm{~ms}$; average power density, $0.3 \mathrm{~mW} / \mathrm{cm}^{2}$; repetition frequency, $4.0 \mathrm{~Hz}$; intermittently for $1 \mathrm{~min}$, 'On' for $1 \mathrm{~min}$, and 'Off' for $10 \mathrm{~min}$; SAR, $0.7 \mathrm{~mW} / \mathrm{g}$ ) and 5 were in the sham group. The authors detected the EEG within the frequency bands of 0.5$30.0 \mathrm{~Hz}$ for 5 consecutive days. The results showed that in normal EEGs, the $\theta(3.2-6.0 \mathrm{~Hz})$ and $\beta_{2}(17.8-$ $30.5 \mathrm{~Hz}$ ) waves were mainly concentrated in the cortex, while the $\alpha(6.0-17.8 \mathrm{~Hz})$ waves were mainly

Table 3 The influence of microwave radiation on learning and memory

\begin{tabular}{|c|c|c|c|c|c|}
\hline Item & Reference & Method & Sample/Model & Exposure condition & Results \\
\hline \multirow[t]{3}{*}{ Negative effects } & Sareesh et al. 2009 & MWM & $\begin{array}{l}\text { Male Wistar rats } \\
(10-12 \text { weeks old })\end{array}$ & $\begin{array}{l}50 \text { missed calls/day for } 4 \text { weeks from a } \\
\text { GSM ( } 900 / 1800 \mathrm{MHz} \text { ) mobile phone in } \\
\text { vibratory mode (no ring tone) }\end{array}$ & $\begin{array}{l}\text { Mobile phone exposure affected } \\
\text { the acquisition of learned } \\
\text { responses in Wistar rats }\end{array}$ \\
\hline & Wang et al. 2013 & MWM & Male Wistar rats & $\begin{array}{l}2.856 \mathrm{GHz} \text { pulsed microwave field for } \\
6 \mathrm{~min} \text { (unexposed, 5, } 10 \text { and } 50 \mathrm{~mW} / \mathrm{cm}^{2} \text { ) }\end{array}$ & $\begin{array}{l}10 \text { and } 50 \mathrm{~mW} / \mathrm{cm}^{2} \text { displayed } \\
\text { significant deficits inspatial } \\
\text { learning and memory }\end{array}$ \\
\hline & Lai et al. 1994 & $\begin{array}{l}12 \text { radial-arm } \\
\text { maze }\end{array}$ & Rats & $\begin{array}{l}\text { Exposure to pulsed } 2450 \mathrm{MHz} \text { microwaves } \\
\text { for } 45 \mathrm{~min}\end{array}$ & $\begin{array}{l}\text { Deficit in spatial "working } \\
\text { memory" function }\end{array}$ \\
\hline \multirow[t]{3}{*}{ Neutral effects } & Cassel et al. 2004 & $\begin{array}{l}12 \text { radial-arm } \\
\text { maze }\end{array}$ & Rats & $\begin{array}{l}2.45 \mathrm{GHz} \text { microwaves ( } 500 \mathrm{pps} \text {, pulse } \\
\text { width }=2 \mathrm{\mu s} \text {, average whole body SAR } \\
=0.6 \mathrm{~W} / \mathrm{kg} \text { for } 45 \mathrm{~min} \text { ) }\end{array}$ & $\begin{array}{l}\text { Microwave-induced behavioral } \\
\text { alterations measured by Lai had } \\
\text { more to do with factors related } \\
\text { to performance bias than to } \\
\text { spatial working memory }\end{array}$ \\
\hline & Cosquer et al. 2005 & $\begin{array}{l}12 \text { radial-arm } \\
\text { maze }\end{array}$ & Rats & $\begin{array}{l}\text { Whole-body exposure to } 2.45 \mathrm{GHz} \\
\text { electromagnetic fields }\end{array}$ & $\begin{array}{l}\text { Radial-arm maze performance } \\
\text { in rats did not changed }\end{array}$ \\
\hline & Cobb et al. 2004 & $\begin{array}{l}12 \text { radial-arm } \\
\text { maze }\end{array}$ & Rats & $\begin{array}{l}45 \text { min exposure to } 2450 \mathrm{MHz} \text { fields at } \\
\text { whole body SARs of } 0.6 \mathrm{~W} / \mathrm{kg} \text { (500pps, } \\
\text { pulse width = } 2 \mu \mathrm{\mu s}) \text {; pre-exposure injection } \\
\text { of one of three psychoactive compounds } \\
\text { or saline }\end{array}$ & $\begin{array}{l}\text { Exposure to microwave radiation } \\
\text { did not cause decrements in the } \\
\text { ability of rats to learn the spatial } \\
\text { memory task }\end{array}$ \\
\hline
\end{tabular}


concentrated in the hypothalamus. After exposure, the levels of $\beta_{2}$ waves in the hypothalamus increased more than those in the cortex, leading to a significant reduction in the deviation of the two EGGs. The results indicated that repeated low-level exposure to extremely low frequency microwaves affects brain functioning and provide an additional approach to analyzing the underlying mechanisms.

In a study investigating the influence of low-frequency microwave $(450 \mathrm{MHz})$ radiation on EEG, Hinrikus et al. [49] found that microwave radiation enhanced brain wave energy, decreased brain wave frequency, and increased the amplitude and power of delta frequency bands, indicating a decrease in learning ability [50-53]. More data are available regarding opinions on potential health effects of exposure to electromagnetic fields [3].

Many recent studies have reported that microwaves exposure affects EEG results [54-57]. Suhhova et al. [58] exposed volunteers to microwaves at a frequency of $450 \mathrm{MHz}$ for 10 repeated intervals of $1 \mathrm{~min}$ of irradiation and $1 \mathrm{~min}$ off. The SAR of the two groups were $0.303 \mathrm{~W} / \mathrm{kg}$ and $0.003 \mathrm{~W} / \mathrm{kg}$. A resting eyes-closed electroencephalogram was used to continuously record the results, which showed that there was an increase in the power of the $\alpha, \beta_{1}$ and $\beta_{2}$ frequency bands in the $0.303 \mathrm{~W} / \mathrm{kg}$ group and in the $\beta_{2}$ frequency bands in the $0.003 \mathrm{~W} / \mathrm{kg}$ group. Statistically significant changes were detected in the EEG- $\alpha$ bands of six individuals and in the $\beta_{1}$ and $\beta_{2}$ bands of four subjects in the higher SAR group. In the lower SAR group, the $\alpha, \beta_{1}$ and $\beta_{2}$ bands were affected in the three subjects. This study also revealed the dose-dependent relationship of the modulated microwave effect: decreasing the SAR 100-fold reduced the associated changes in the EEG by three- to six-fold and decreased the number of affected subjects but did not completely eliminate the effects.

\section{The influence of microwave radiation on postnatal development}

Maternal exposure to $\mathrm{Wi}-\mathrm{Fi}$ radio frequencies led to various adverse neurological effects in the offspring. Othman et al. [59] exposed Wistar albino pregnant rats to a $2.45 \mathrm{GHz} \mathrm{Wi}$-Fi signal for $2 \mathrm{~h} / \mathrm{d}$ throughout the gestation period and found that the neurodevelopment, cerebral stress equilibrium and cholinesterase activity of the offspring were affected. To investigate the potential combined influence of maternal restraint stress and $2.45 \mathrm{GHz}$ Wi-Fi signal exposure on postnatal development and behavior in the offspring of exposed rats, control, Wi-Fi-exposed, restrained and both Wi-Fi-exposed and restrained groups were established. Each Wi-Fi exposure and restraint occurred for $2 \mathrm{~h} / \mathrm{d}$ during gestation until parturition. The results showed that gestational Wi-Fi exposure and restraint adversely affected offspring neurodevelopment and behavior in adulthood. The progeny brain oxidative balance and serum biochemistry, such as phosphorus, magnesium, glucose, triglycerides and calcium levels, were disrupted [60].

Zhang et al. [61] found that after pregnant rats were irradiated with $9.417 \mathrm{GHz}$ microwaves, the behavior of their offspring differed, and the outcome was sexdependent. An increase in anxiety-related behaviors and a decrease in depression-related behavior were observed in both female and male offspring. However, impaired learning and memory were only observed in males. Zhang proposed that the sex-dependent relationship between microwaves and the behavior of offspring may be related to sex hormones, and female rats may be equivalently protected by reducing oxidative stress levels.

\section{Mechanisms underlying learning and memory are damaged by microwave irradiation \\ Synaptic structures and functions}

Synapses are special structures that are involved in the transmission of electrochemical signals between neurons in the central nervous system. Synaptic plasticity is a special function of synapses, which play an important role in learning and memory processes [46], including structural and functional plasticity. After exposure to microwave radiation, during synaptic structural plasticity, presynaptic vesicles accumulate or empty, mitochondria are damaged, postsynaptic membranes are perforated, postsynaptic lengths and postsynaptic density distributions are abnormal, mossy fiber growth is inhibited during learning and memory functions, dendritic filopodial densities and activities are decreased, and there is a significant reduction of the dendritic spine density and dendritic fragment length [62]. Functional plasticity is affected in other ways, including the abnormal release and uptake of brain amino acids such as choline and monoamine neurotransmitters, a decrease in excitatory postsynaptic potential amplitudes and spikes in long-term potentiating (LTP) in the medial perforated pathway (MPP) in the dentate gyrus (DG) [27].

\section{In vitro studies}

Ning et al. [63] exposed rat hippocampal neurons to microwaves (SAR values of $0.8 \mathrm{~W} / \mathrm{kg}$ and $2.4 \mathrm{~W} / \mathrm{kg}$ at an average power density of $1800 \mathrm{MHz} / \mathrm{d}$ ) and observed the formation of dendritic filopodial and dendritic branches and the maturation of dendritic spines in neurons from day 6 to 14. Additionally, in the $2.4 \mathrm{~W} / \mathrm{kg}$ group, neuronal filopodial density and activity were lower on day 8 , and there was a reduction of the dendritic spine maturity on day 14 . In the group treated with $0.8 \mathrm{~W} / \mathrm{kg}$, there was no significant change. Thus, in the early developmental stage, chronic exposure to $2.4 \mathrm{~W} / \mathrm{kg}$ GSM microwaves may influence dendritic development and the 
formation of excitatory synapses in cultures of hippocampal neurons. Xu et al. [64] exposed cultured rat hippocampal neurons to GSM $1800 \mathrm{MHz}$ microwaves (SAR, $2.4 \mathrm{~W} / \mathrm{kg}$ ) and observed a selective decrease in the amplitude of $\alpha$-amino-3-hydroxy-5-methyl-4-soxazole propionic acid (AMPA) miniature excitatory postsynaptic currents (mEPSCs). However, there was no change in the frequency of AMPA mEPSCs or the amplitudes of N-methyl-d-aspartate (NMDA) mEPSCs. Furthermore, the expression of postsynaptic density 95 (PSD-95) in cultured neurons was decreased. Thus, these results suggest that the $2.4 \mathrm{~W} / \mathrm{kg}$ GSM $1800 \mathrm{MHz}$ microwaves may reduce excitatory synaptic activity and the number of excitatory synapses in cultured rat hippocampal neurons.

\section{In vivo studies}

Wang et al. [65] irradiated Wistar rats with 10, 30 and $50 \mathrm{~mW} / \mathrm{cm}^{2}$ microwaves, and the results showed that in the cerebral cortex, only glycine (Gly) and asparagine (Asp) levels were increased. Microwaves of $50 \mathrm{~mW} / \mathrm{cm}^{2}$ increased the levels of the major excitatory amino acids Asp and glutamic acid (Glu) and the inhibitory amino acids gamma-aminobutyric acid (GABA) and Gly, while $6 \mathrm{~h}$ later in the $30 \mathrm{~mW} / \mathrm{cm}^{2}$ group, the level of Gly was reduced in the cerebral cortex. However, $\mathrm{Li}$ et al. [50] exposed Wistar rats to $2.856 \mathrm{GHz}$ microwaves at an average power density of $5,10,20$ or $30 \mathrm{~mW} / \mathrm{cm}^{2}$ for 6 min three times per week for up to 6 weeks and found that on day 14 after irradiation, the levels of Asp and Glu were lower in the hippocampus in the group treated with $5 \mathrm{~mW} / \mathrm{cm}^{2}$ but higher in the group treated with $30 \mathrm{~mW} / \mathrm{cm}^{2}$, The levels of GABA were elevated. After 28 days, the levels of Glu and Tau in the hippocampus and cerebrospinal fluid were lower, indicating that the cognitive damage induced by microwave radiation is associated with a decrease in Glu [66, 67].

Synaptic vesicles form in different parts of neurons and contain high concentrations of substances that are transferred from the neuron. When nerve endings are excited, the vesicles release their contents into the synaptic cleft, resulting in synaptic transmission. The normal function of synaptic vesicles depends on the normal expression of related proteins. Wang et al. [68] radiated Wistar rats with microwaves $\left(30 \mathrm{~mW} / \mathrm{cm}^{2}\right.$; SAR value, $14.1 \mathrm{~W} / \mathrm{kg}$ ), and then detected the expression of synaptic vesicle-associated proteins and found that synaptophys in I and VAMP-2, which are synaptic fusion proteins, and synaptic vesicle proteins were abnormally expressed to different degrees. The authors therefore proposed that synaptic conduction disorders are associated with damage to cognitive functions. Qiao et al. [62] irradiated Wistar rats, hippocampal synaptosomes and differentiated PC12 cells using microwaves (average power density, $30 \mathrm{~mW} / \mathrm{cm}^{2}$ ) for $5 \mathrm{~min}$, and the results showed that the post-exposure spatial memory of the rats was significantly decreased, the post-exposure levels of phosphorylated synapsin I (p-synapsin I) and GABA were decreased in the rat and cell experiments, and the post-exposure levels of vesicular GABA transporter and p-synapsin I were increased in small clear synaptic vesicles (which were abnormally assembled in presynaptic terminals) in the rat experiments. Exposure to microwaves and silencing p-synapsin I reduced the release of GABA, and maximum reduction was achieved when both were combined, indicating a synergistic effect. Xu et al. found that long-term treatment with a low dose of microwave radiation reduced the activity and the number of excitatory synapses.

\section{NMDA receptors}

Among the variety of neurotransmitters, glutamate is the most abundant endogenous amino acid in the mammalian central nervous system. It influences both learning and memory in rats [67]. In the CNS, glutamic acid binds and plays physiological roles with the following two receptors: ionotropic glutamate and metabolic glutamate. The ionotropic receptors consist of NMDA receptors and non-NMDA receptors.

$\mathrm{N}$-methyl-D-aspartic acid receptor (NMDAR) is a tetramer composed of two NR1 and two NR2 subunits or two NR3 subunits that perform the functions of NMDAR [69, 70], and NMDAR plays key roles in synapse development, synaptic plasticity and neurological diseases. LTP induction involves a signal transduction cascade that includes the release of glutamate from synaptic vesicles, activation of NMDAR at postsynaptic membranes, entry of $\mathrm{Ca}^{2+}$, and activation of $\mathrm{Ca}^{2+} / \mathrm{cal}-$ modulin-dependent protein kinases (CaM kinases) II, IV and mitogen-activated protein kinase (MAPK) [71]. Xiong et al. [46] found that by excessively activating the NMDA receptor signaling pathway, microwaves undermine hippocampal synaptic plasticity, explaining the damage observed in learning and memory abilities in radiated rats. Wang et al. [72] found that $2.856 \mathrm{GHz}$, $50 \mathrm{~mW} / \mathrm{cm}^{2}$ pulsed microwave radiation caused persistent spatial memory impairments, disordered neurotransmitters, and varying degrees of damage in the hippocampus and synapses. The levels of NMDA receptor subunits were increased 1 month after irradiation. NR2B plays a key role in LTP and was decreased from the 3rd to the 18th month post-treatment, and longterm exposure to high doses of radiation may therefore damage cognitive functions. This effect is similar to the decrease observed in NR2B in rats. It has also been reported that acute exposure to continuous waves of $900 \mathrm{MHz}$ EMF or $900 \mathrm{MHz}$ waves that were modulated to an amplitude of $50 \mathrm{~Hz}$ increased reactive oxygen 
species (ROS) levels and DNA fragmentation as a result of the hyperstimulation of glutamate receptors [73].

\section{Oxidative stress and apoptosis}

Oxidative stress refers to an imbalance between oxidants and antioxidants in vivo and is characterized by a biochemical state that tends toward oxidization, including the formation of oxygen free radicals (i.e., ROS) and nitrogen radicals reactive nitrogen species (RNS), which play major roles in oxidation. Numerous mechanisms can activate oxidative stress, including electromagnetic radiation, and thereby cause molecular damage. This damage plays a key role in the structural and functional changes that are accelerated by neuronal degeneration. It has been reported that microwave radiation can induce lipid peroxidation of cell membranes and produce apoptotic signals [74, 75]. Microwave radiation can induce oxidative and nitrosative stress, which lead to hippocampal neuronal and non-neuronal apoptosis via the oxidative damage of cellular constituents (i.e., nucleic acids, proteins and lipids) and subsequent over expression of p53, which up-regulates Bax and down-regulates pro-caspase-3 and full-length/uncleaved poly-ADPribose polymerase (PARP) 1, eventually inducing neuronal degeneration via apoptosis [76]. Chronic microwave exposures were executed with $2.45 \mathrm{GHz}$ of either modulated (power density, $0.029 \mathrm{~mW} / \mathrm{cm}^{2}$; specific absorption rate, $0.019 \mathrm{~W} / \mathrm{kg}$ with a sinusoidal modulation of $400 \mathrm{~Hz}$ ) or non-modulated continuous sinusoidal wave (power density, $0.033 \mathrm{~mW} / \mathrm{cm}^{2}$; specific absorption rate, $0.023 \mathrm{~W} / \mathrm{kg}$ ) for $2 \mathrm{~h}$ daily for 1 month. The results suggested that chronic non-modulated, but not modulated, microwave radiation may cause anxiety-like and depression-like behaviors and calcium- and NO-related biochemical changes in the brain [77].

\section{In vitro studies}

Shahin found that regardless of whether exposure was long-term or short-term, $2.45 \mathrm{GHz}$ microwaves increased oxidative/nitrosative stress, which potentially led to apoptosis in hippocampal subfield neurons and nonneuronal cells as a result of p53-dependent/-independent activation. Mack et al. [78] exposed differentiated astroglial cells that were cultured for 14 days in vitro to either continuous $900 \mathrm{MHz}$ waves or $900 \mathrm{MHz}$ waves modulated in amplitude at $50 \mathrm{~Hz}$ using a sinusoidal wave form and $100 \%$ modulation index for 5,10 , or $20 \mathrm{~min}$. The strength of the electric field ( $\mathrm{rms}$ value) at the sample position was $10 \mathrm{~V} / \mathrm{m}$. A significant increase in ROS levels and DNA fragmentation were observed only after the astrocytes were exposed to modulated EMF for $20 \mathrm{~min}$, perhaps as a result of hyperstimulation of glutamate receptors. To investigate the effects of microwaves radiation on apoptotic activity, cell viability, and cell cycle progression, which can provide information about microwaves radiation effects on neural cells over the period from embryonic stages to infants. $\mathrm{Hu}$ man SH-SY5YNB cells were exposed to $2.1 \mathrm{GHz}$ WCDMA modulated microwave radiation for $24 \mathrm{~h}$ at a specific absorption rate of $0.491 \mathrm{~W} / \mathrm{kg}$. The results showed that $2.1 \mathrm{GHz}$ W-CDMA-modulated microwave radiation did not cause apoptotic cell death but altered cell cycle progression [79].

\section{In vivo studies}

Joubert et al. [80] found that irradiation with $900 \mathrm{MHz}$, $2 \mathrm{~W} / \mathrm{kg}$ continuous microwaves for $24 \mathrm{~h}$ induced an increase in rat neuronal apoptosis. Motawi et al. [81] reported a study exploring the influence of mobile phone microwave radiation on oxidative stress and apoptosis in rat brains. The experimental rats were divided into six groups of 3 adult rats and 3 young rats in each group (with control, GSM alone and call-receiving subgroups in each group). After irradiation was applied for $2 \mathrm{~h} / \mathrm{d}$ for $60 \mathrm{~d}$, the authors observed the following: microwave radiation produced by mobile phones damaged the brains of adult and young rats, the damage caused by mobile phones in the calling state was significantly more severe than that observed in the standby group, and the neurons of young rats were more seriously injured than those of adult rats. The direct cause of the observed neuronal damage may have been apoptosis induced by the microwave radiation, and an indirect cause may have been an increase in permeability of the blood-brain barrier (BBB), which would allow the traversal of toxic substances that could cause damage. Dasdag et al. [82] exposed animals to $900 \mathrm{MHz}$ microwave radiation for $2 \mathrm{~h} / \mathrm{d}$ for 10 months and removed the brain tissues. The final apoptosis score in the exposed group was significantly reduced, and the total antioxidant capacity and catalysis observed in the experimental group was increased. Therefore, the authors concluded that exposure to a radiofrequency of $900 \mathrm{MHz}$ might trigger the neoplastic process because it produces a relative increase in the number of potentially long-lived cells.

\section{Protein synthesis}

It is widely accepted that protein synthesis occurs in neuronal dendrites and may be the cellular basis of learning and memory, during which local protein synthesis and synaptic plasticity are closely linked to the efficiency of communication between neurons. The effects of microwave radiation on protein synthesis in brain remain undetermined.

Fragopoulou et al. [83] found that long-term exposure to microwave radiation (typical mobile phone, at an SAR level range of $0.17-0.37 \mathrm{~W} / \mathrm{kg}$ for $3 \mathrm{~h}$ daily for 8 months, or wireless digital enhanced cordless telecommunications/ 
telephone (DECT) base at an SAR level range of 0.012$0.028 \mathrm{~W} / \mathrm{kg}$ for $8 \mathrm{~h} / \mathrm{d}$ for 8 months) induced the synthesis of 143 proteins, including some neuronal functionassociated proteins such as glial fibrillary acidic protein (GFAP), glial maturation factor (GMF), apolipo protein E, heat-shock protein, cytoskeletal proteins and some proteins that are associated with metabolism in the brain.

Verma et al. [84] and Sharma et al. [85] found that protein levels were reduced in rat brains following microwave radiation, which may have been caused by the excessive consumption or a reduction of the synthesis of proteins, and reduced protein synthesis can be caused by the following processes: (1) excessive activation of RNA enzymes; (2) mRNA consumption or the formation and maturation of RNA enzymes. Microwave radiation can cause tissue damage by inducing localized microstructural damage to proteins $[86,87]$. It has been reported that microwave radiation can decrease both the number and the density of dendritic spines [63]. Dendritic spines, which are small protrusions that extend from dendritic shafts, are also cellular compartments containing signaling molecules that are important for synaptic transmission and plasticity [88-91]. These spines have been reported to share a close relationship with learning and memory abilities, and when protein synthesis in dendritic spines is blocked, new spine growth and the development of long spines are both decreased [91].

Dasdag et al. [92] found that $900 \mathrm{MHz}$ microwave radiation emitted by mobile phones increased protein carbonyl levels in the brains of rats, suggesting that $900 \mathrm{MHz}$ microwave radiation can alter some biomolecules such as proteins.

In summary, there is evidence that microwave radiation can lead to alterations in protein synthesis or protein modifications; however, the results are controversial. This phenomenon may be explained by the varied radiation dosage adopted in these studies.

\section{Genes and individual susceptibility}

miRNAs are non-coding sequences with a length of approximately 22 nucleotides that have roles in cell development and differentiation and are also linked to signal transduction and tumorigenesis. Some studies have proposed that miRNAs play important roles in nerve regeneration, neurodegenerative diseases, and the pathogenesis of neuroblastoma and schizophrenia [93-95]. More than $50 \%$ of miRNAs are found in cancer-associated regions of the genome or in fragile sites, suggesting that miRNAs also play important roles in the pathogenesis of neoplasias [96]. Dasdag et al. [97] found that long-term exposure to $900 \mathrm{MHz}$ radiation decreased the level of rno-miR107and that the whole body (rms) SAR value was $0.0369 \mathrm{~W} / \mathrm{kg}$, bridging the gap in the interaction between radio frequency radiation (FR) and miRNAs. Studies have also suggested that long-term exposure to $2.4 \mathrm{GHz}$ microwave radiation may lead to adverse effects, as observed in neurodegenerative diseases that originate from the altered expression of some miRNAs. The authors found that $2.4 \mathrm{GHz}$ microwave radiation reduced the expression of some miRNAs such as miR-106b-5p and miR-107 [98]. Zhao et al. [99] used a microarray and quantitative realtime PCR to analyze the miRNA expression profile in the hippocampus on days 7 and 14 after irradiation with a microwave at $30 \mathrm{~mW} / \mathrm{cm}^{2}$. The authors predicted the differential expression of genes associated with transcription, translation and receptor functions (in addition to brainrelated and signaling pathway-related) using the iRDB, miRbase and miRanda databases. They summarized the characteristics and functions of hippocampus-related miRNAs following irradiation with microwaves, and these data laid a foundation that clarified the molecular mechanisms underlying microwave-induced injury to hippocampal learning and memory and suggested potential therapeutic targets. To investigate the effects of $2.4 \mathrm{GHz}$ Wi-Fi radiation on multisensory integration in rats, a cross-modal visual-tactile object recognition (CMOR) task was performed by four variations of the spontaneous object recognition (SOR) test including the standard SOR, tactile SOR, visual SOR, and CMOR tests. The results of this study showed that chronic exposure to Wi-Fi electromagnetic waves might impair both unimodal and cross-modal encoding of information. The increase in M1 receptor gene expression along with the impairment of novel preferences in Wi-Fi-exposed animals may suggest a possible role of the cholinergic system in the detrimental effects of Wi-Fi radiation on multisensory integration [100].

Megha et al. [101] exposed rats to microwave radiation at frequencies of $0,900,1800$ and $2450 \mathrm{MHz}$ (SARs: 0, $0.59,0.58$ and $0.66 \mathrm{~mW} / \mathrm{kg}$, respectively) using a transverse electromagnetic cell for 2 months for $2 \mathrm{~h} / \mathrm{d}, 5 \mathrm{~d} /$ week. Subsequently, significantly more DNA damage was observed in the exposed groups than in the sham group, and their study also indicated that oxidative stress and inflammation caused DNA damage in response to lowintensity microwave exposure. To investigate whether exposure of rat brains to GMS microwaves induced DNA breaks and changes in gene expression, Belyaev et al. [102] exposed rats to $9.15 \mathrm{MHz}$ microwaves (SAR: $0.4 \mathrm{~mW} / \mathrm{g}$ ) for $2 \mathrm{~h}$. They found that in the cerebellum of all the exposed animals, 11 genes were up-regulated from 1.34- to 2.74-fold, and one gene was down-regulated 0.48 -fold. The induced genes encoded proteins with a variety of functions, including neurotransmitter regulation, BBB maintenance, and melatonin production. The study also showed that exposure to GSM microwaves at $915 \mathrm{MHz}$ did not induce detectable DNA double-strand breaks but affected the expression of genes in rat brain cells. 
Merola et al. [103] found that microwave radiation caused DNA single-strand and double-strand breaks in vivo in populations submitted to occupational exposure, and the incidence of micronuclei in lymphocytes was significantly increased. However, other reports have indicated that unlike ionizing radiation, the microwave radiation produced by mobile phones does not possess sufficient energy to directly damage DNA. Most bioassay and genotoxicity or mutation studies that have been performed in vitro have reported that exposure to microwave radiation at non-thermal levels does not have mutagenic/genotoxic/carcinogenic effects. Qutob et al. [104] found that exposure to a $1.9 \mathrm{GHz}$ pulse-modulated RF field for $4 \mathrm{~h}$ at $0.1,1.0$, and $10 \mathrm{~W} / \mathrm{kg}$ did not affect gene expression in U87MG glioblastoma cells.

Starting with a single nucleotide polymorphism (SNP) site, Wang et al. [105] identified stable C-T mutation sites at 217 points by screening for SNPs in the GRIN2B promoter region in rats. After exposure to microwave irradiation (an average power density of $30 \mathrm{~mW} / \mathrm{m}^{2}$ for $5 \mathrm{~min} / \mathrm{d}$ on five days a week for two consecutive months), the expression of NR2B was decreased in rats, the level of Glu was increased in the hippocampus and cerebrospinal fluid, spatial memory ability was decreased among rats with the TT genotype, and there was no change in the CC type and TC type animals. In the cell experiments, the $\mathrm{T}$ allele was significantly more vulnerable to microwaves than the $\mathrm{C}$ allele with regard to its transcription factor binding ability and the transcriptional activity and mRNA and protein expression of NR2B. These results explain the genetic mechanisms by which microwave radiation induces damage to learning and memory.

\section{Energy metabolism}

Glucose is the main energy source and is closely related to brain neurotransmitters and cholesterol synthesis [106]. In addition, glucose is also related to cognitive functions, and reductions in the metabolism and uptake of glucose have been observed in local regions of the brain in Alzheimer's patients [107, 108]. Damage to learning abilities and reduction of glucose utilization in the limbic system of adult rats are closely linked [109]. In the rat hippocampus, glucose uptake plays an important role in spatial learning and memory processes. The rats in the study showed increases in spatial memory and glucose transporters, and this phenomenon indicated a corresponding increase in glucose uptake. In contrast, a central injection of a glucose carrier inhibitor induced injury to memories [110]. Kwon et al. [111] found that the rate of glucose metabolism in the brains of rats was lower after short-term exposure to microwave radiation, and the blood glucose management reduced the damage that was caused by microwave radiation due to the decreased glucose uptake $\left(2.45 \mathrm{MHz}, 1 \mathrm{~mW} / \mathrm{cm}^{2}\right.$, continuous radiation for $30 \mathrm{~d}$ at $3 \mathrm{~h} / \mathrm{d}$ ), as were learning and memory capacity. The mechanism by which microwave radiation decreases glucose, resulting in impaired learning and memory in rats, may be related to an increase in the synthesis and release of acetylcholine in the hippocampus. Numerous studies have shown that increased acetylcholine is related to promotion of the effect of glucose on memory [112-114]. Concurrently, in the hippocampus, acetylcholine can promote learning and memory $[115,116]$. An increasing level of acetylcholine can increase the concentration of free calcium ions in synapses, but its concentration was decreased by $60 \%$ after exposure to microwave irradiation [117]. It has been proposed that by enhancing the functions of acetylcholine, glucose can increase the concentration of free calcium ions in the synapse to reverse microwave-induced damage to learning and memory.

It has been shown that neurons are sensitive to reductions in the availability of adenosine triphosphate (ATP), the main source of energy in mitochondria, which have been reported to be vulnerable to microwave radiation [118]. Microwaves can influence mitochondria by damaging their structure [45], reducing ATP levels and affecting the activity of relevant enzymes such as succinate dehydrogenase (SDH) and cytochrome coxidase (COX) [119-121]. The potential mechanisms underlying these damaging effects range from gene expression alterations in the respiratory chain, membrane damage, $\mathrm{Ca}^{2+}$ overloading, and DNA impairment [122-128].

\section{Summary}

It is noteworthy that most of the above mentioned studies were based on the theory that the effects caused by microwaves are non-thermal. However, a recent report [3] published by the Scientific Committee on Emerging and Newly Identified Health Risks (SCENIHR) noted that discussions about the thermal and non-thermal effects are misleading. Because the frequency of microwaves is sufficiently high that the energy is absorbed, the subsequent heating of tissue becomes its major mechanism, and most biochemical and physiological responses are temperature-dependent. Thus, the committee suggested that in the future, studies should explore the border between thermal and non-thermal effects and that specific effects, such as triggering the onset of thermoregulatory reactions, should be defined.

\section{Conclusion}

With the popularity of microwave technology, microwave effects on the human body have become a common topic of concern, and the central nervous system is recognized as a target organ system that is sensitive to 
microwave radiation. However, to date, with the exception of high-power microwave radiation, which has widely established hazardous effects, the biological effects of microwaves remain controversial. In epidemiology, there is no conclusive evidence showing that microwaves have carcinogenic effects. Concurrently, the discovery that microwaves have positive biological effects has presented new challenges for research and applications in this field. The results of EEG and analyses of the structure of the brain after radiation have also confirmed the influence of microwaves. Studies have extensively explored the underlying mechanisms by which microwaves influence learning and memory functions, especially synaptic structures and functions, oxidative stress and apoptosis, protein synthesis, genes and individual susceptibility and energy metabolism. Previous studies have produced a large amount of information, and some progress has been made in theory, but the mechanisms have not yet been fully determined, and many points are still disputed. The largest problem in these studies is that they used different parameters, such as the frequency, modulation, power density and irradiation time, to apply microwave radiation, in addition to using a variety of research methods. Therefore, their reproducibility and comparability are poor. To determine the precise dose-effect relationship between microwave radiation and its biological effects, further detailed studies must be performed.

\footnotetext{
Abbreviations

AMPA: a-amino-3-hydroxy-5-methyl-4-soxazole propionic acid; Asp: Asparaginic acid; ATP: Adenosine triphosphate; BBB: Blood-brain barrier;

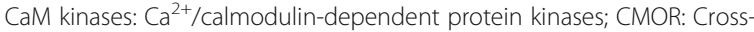
modal visual-tactile object recognition; COX: Cytochrome coxidase; CTFs: Carboxyl-terminal fragments; DECT: Digital enhanced cordless telecommunications/telephone; DG: Dentate gyrus;

EEG: Electroencephalograph; EMF: Electric magnetic field; FR: Frequency radiation; GABA: Gamma-aminobutyric acid; GFAP: Fibrillary acidic protein; Glu: Glutamic acid; Gly: Glycine; GMF: Glial maturation factor; GSM: Global system for mobile communication; IARC: International agency for research on cancer; LTP: Long term potentiation; MAPK: Mitogen-activated protein kinase; MEPSCs: Miniature excitatory postsynaptic currents; MPP: Medial perforant path; MRI: Magnetic resonance imaging; NMDA: N-methyl-Daspartate; NMDAR: N-methyl-D-aspartic acid receptors; PARP: Poly-ADP-ribose polymerase; PSD-95: Postsynaptic density 95; RNS: Reactive nitrogen species; ROS: Reactive oxygen species; SAR: Specific absorption rate;

SCENIHR: Scientific committee on emerging and newly identified health risks; SDH: Succinate dehydrogenase; SNP: Single nucleotide polymorphism; SOR: Spontaneous object recognition
}

\section{Acknowledgements}

Not applicable.

\section{Funding}

This work was supported by the National Natural Science Foundation of China (61571455).

Availability of data and materials Not applicable.

\section{Authors' contributions}

WJZ wrote the paper and outlined this manuscript, LFW and XJH provided a detailed guidance throughout the article. All of the authors read and approved the final manuscript.
Ethics approval and consent to participate

Not applicable.

\section{Consent for publication}

Not applicable.

\section{Competing interests}

The authors declare that they have no competing interests.

Received: 26 March 2017 Accepted: 9 September 2017

Published online: 21 September 2017

References

1. Vorobyov V, Janac B, Pesic V, Prolic Z. Repeated exposure to low-level extremely low frequency-modulated microwaves affects cortexhypothalamus interplay in freely moving rats: EEG study. Int J Radiat Biol. 2010;86:376-83.

2. Eliyahu I, Luria R, Hareuveny R, Margaliot M, Meiran N, Shani G. Effects of radiofrequency radiation emitted by cellular telephones on the cognitive functions of humans. Bioelectromagnetics. 2006;27:119-26.

3. Sage C, Carpenter D, Hardell L. Comments on SCENIHR: opinion on potential health effects of exposure to electromagnetic fields. Bioelectromagnetics. 2015;36:480-4

4. Szmigielski S. Cancer risks related to low-level RF/MW exposures, including cell phones. Electromagn Biol Med. 2013;32:273-80.

5. Kan P, Simonsen SE, Lyon JL, Kestle JR. Cellular phone use and brain tumor: a meta-analysis. J Neuro-Oncol. 2008;86:71-8.

6. Khurana VG, Teo C, Kundi M, Hardell L, Carlberg M. Cell phones and brain tumors: a review including the long-term epidemiologic data. Surg Neurol. 2009:72:205-14.

7. Myung SK, Ju W, McDonnell DD, Lee YJ, Kazinets G, Cheng CT, et al. Mobile phone use and risk of tumors: a meta-analysis. J Clin Oncol. 2009;27: 5565-72.

8. Johansen C, Boice JD, McLaughlin JK, Olsen JH. Cellular telephones and cancer-a nationwide cohort study in Denmark. J Natl Cancer Inst. 2001;93: 203-7.

9. Muscat JE, Malkin MG, Thompson S, Shore RE, Stellman SD, McRee D, et al. Handheld cellular telephone use and risk of brain cancer. JAMA. 2000; 284:3001-7.

10. Lönn S, Ahlbom A, Hall P, Feychting M. Long-term mobile phone use and brain tumor risk. Am J Epidemiol. 2005;161:526-35.

11. Frei P, Poulsen AH, Johansen C, Olsen JH, Steding-Jessen M, Schüz J. Use of mobile phones and risk of brain tumours: update of Danish cohort study. BMJ. 2011;343:522-4.

12. Schüz J, Jacobsen R, Olsen JH, Boice JD, McLaughlin JK, Johansen C. Cellular telephone use and cancer risk: update of a nationwide Danish cohort. J Nat| Cancer Inst. 2006;98:1707-13.

13. Interphone study group. Brain tumour risk in relation to mobile telephone use: results of the INTERPHONE international case-control study. Int J Epidemiol. 2010;39:675-94

14. Larjavaara S, Schüz J, Swerdlow A, Feychting M, Johansen C, Lagorio S, et al. Location of gliomas in relation to mobile telephone use: a case-case and case-specular analysis. Am J Epidemiol. 2011;174:2-11.

15. Hardell L, Carlberg M, Mild KH, Eriksson M. Case-control study on the use of mobile and cordless phones and the risk for malignant melanoma in the head and neck region. Pathophysiology. 2011;18:325-33.

16. Dasdag S, Balci K, Celik M, Batun S, Kaplan A, Bolaman Z, et al. Neurologic and biochemical findings and CD4/CD8 ratio in people occupationally exposed to RF and microwave. Biotechnol Biotechnol Equip. 1992;6:37-9.

17. Oto R, Akdağ Z, Daşdağ $S$, Celik Y. Evaluation of Psychologic parameters in people occupationally exposed to radiofrequencies and microwave. Biotechnol Biotechnol Equip. 1994;8:71-4.

18. Mortazavi SMJ, Taeb S, Dehghan N. Alterations of visual reaction time and short term memory in military radar personnel. Iran J Public Health. 2013;42:428.

19. Naser D, Shahram T. Adverse health effects of occupational exposure to radiofrequency radiation in airport surveillance radar operators. Indian J Occup Environ Med. 2013;17:7-11.

20. Singh S, Mani KV, Kapoor N. Effect of occupational EMF exposure from radar at two different frequency bands on plasma melatonin and serotonin levels. Int J Radiat Biol. 2015;91:426-34. 
21. Richter ED, Berman T, Ben-Michael E, Laster R, Westin JB. Cancer in radar technicians exposed to radiofrequency/microwave radiation: sentinel episodes. Int J Occup Environ Health. 2000;6:187-93.

22. Richter ED, Berman T, Levy O. Brain cancer with induction periods of less than 10 years in young military radar workers. Arch Environ Health. 2002:57:270-2.

23. Szmigielski S. Cancer morbidity in subjects occupationally exposed to high frequency (radiofrequency and microwave) electromagnetic radiation. Sci Total Environ. 1996;180:9-17.

24. Otto M, von Mühlendahl KE. Electromagnetic fields (EMF): do they play a role in children's environmental health $(\mathrm{CEH})$ ? Int J Hyg Environ Health. 2007;210:635-44.

25. Aydin D, Feychting M, Schüz J, Andersen TV, Poulsen AH, Prochazka M, et al. Predictors and overestimation of recalled mobile phone use among children and adolescents. Prog Biophys Mol Biol. 2011;107:356-61.

26. Mortazavi S, Tavakkoli-Golpayegani A, Haghani M, Mortazavi S. Looking at the other side of the coin: the search for possible biopositive cognitive effects of the exposure to $900 \mathrm{MHz}$ GSM mobile phone radiofrequency radiation. J Environ Health Sci Eng. 2014;12:75.

27. Mortazavi S, Rouintan M, Taeb S, Dehghan N, Ghaffarpanah A, Sadeghi Z, et al. Human short-term exposure to electromagnetic fields emitted by mobile phones decreases computer-assisted visual reaction time. Acta Neurol Belg. 2012;112:171-5.

28. Koivisto M, Revonsuo A, Krause C, Haarala C, Sillanmäki L, Laine M, et al. Effects of $902 \mathrm{MHz}$ electromagnetic field emitted by cellular telephones on response times in humans. Neuroreport. 2000;11:413-5.

29. Preece A, Iwi G, Davies-Smith A, Wesnes K, Butler S, Lim E, et al. Effect of a 915-MHz simulated mobile phone signal on cognitive function in man. Int J Radiat Biol. 1999:75:447-56.

30. Koivisto $M$, Krause $C M$, Revonsuo A, Laine $M$, Hämäläinen $H$. The effects of electromagnetic field emitted by GSM phones on working memory. Neuroreport. 2000;11:1641-3.

31. Edelstyn N, Oldershaw A. The acute effects of exposure to the electromagnetic field emitted by mobile phones on human attention. Neuroreport. 2002;13:119-21.

32. Lee TM, Ho SM, Tsang LY, Yang SY, Li LS, Chan CC. Effect on human attention of exposure to the electromagnetic field emitted by mobile phones. Neuroreport. 2001;12:729-31.

33. Smythe JW, Costall B. Mobile phone use facilitates memory in male, but not female, subjects. Neuroreport. 2003;14:243-6.

34. Dasdag S, Balci K, Ayyildiz M, Celik M, Tekes S, Kaplan A. Blood biochemical parameters of the radio-link station. Eastern J Med. 1999;4:10-2.

35. Schüz J, Waldemar G, Olsen JH, Johansen C. Risks for central nervous system diseases among mobile phone subscribers: a Danish retrospective cohort study. PLoS One. 2009;4:e4389.

36. Morris R. Developments of a water-maze procedure for studying spatial learning in the rat. J Neurosci Methods. 1984;11:47-60.

37. Narayanan SN, Kumar RS, Potu BK, Nayak S, Mailankot M. Spatial memory perfomance of wistar rats exposed to mobile phone. Clinics. 2009;64:231-4.

38. Wang $H$, Peng $R$, Zhou $H$, Wang S, Gao $Y$, Wang L, et al. Impairment of long-term potentiation induction is essential for the disruption of spatial memory after microwave exposure. Int J Radiat Biol. 2013;89:1100-7.

39. Lai H, Horita A, Guy AW. Microwave irradiation affects radial-arm maze performance in the rat. Bioelectromagnetics. 1994;15:95-104.

40. Cosquer B, Kuster N, Cassel JC. Whole-body exposure to $2.45 \mathrm{GHz}$ electromagnetic fields does not alter 12-arm radial-maze with reduced access to spatial cues in rats. Behav Brain Res. 2005;161:331-4.

41. Cassel JC, Cosquer B, Galani R, Kuster N. Whole-body exposure to $2.45 \mathrm{GHz}$ electromagnetic fields does not alter radial-maze performance in rats. Behav Brain Res. 2004;155:37-43.

42. Cobb BL, Jauchem JR, Adair ER. Radial arm maze performance of rats following repeated low level microwave radiation exposure. Bioelectromagnetics. 2004;25:49-57.

43. Kesari KK, Behari J. Fifty-gigahertz microwave exposure effect of radiations on rat brain. Appl Biochem Biotechnol. 2009:158:126-39.

44. Li M, Wang Y, Zhang Y, Zhou Z, Yu Z. Elevation of plasma corticosterone levels and hippocampal glucocorticoid receptor translocation in rats: a potential mechanism for cognition impairment following chronic low power-density microwave exposure. J Radiat Res (Tokyo). 2008;49:163-70.

45. Li Z, Peng RY, Wang SM, Wang LF, Gao YB, Ji D, et al. Relationship between cognition function and hippocampus structure after long-term microwave exposure. Biomed Environ Sci. 2012;25:182-8.
46. Xiong L, Sun CF, Zhang J, Gao YB, Wang LF, Zuo HY, et al. Microwave exposure impairs synaptic plasticity in the rat hippocampus and pc12 cells through over-activation of the nmda receptor signaling pathway. Biomed Environ Sci. 2015:28:13-24.

47. Srinivasan R. Anatomical constraints on source models for high-resolution EEG and MEG derived from MRI. Technol Cancer Res Treat. 2006:5:389.

48. Jeong J. EEG dynamics in patients with Alzheimer's disease. Clin Neurophysiol. 2004;115:1490-505.

49. Hinrikus H, Bachmann M, Lass J, Karai D, Tuulik V. Effect of low frequency modulated microwave exposure on human EEG: individual sensitivity. Bioelectromagnetics. 2008;29:527-38

50. Li HJ, Peng RY, Wang CZ, Qiao SM, Yong Z, Gao YB, et al. Alterations of cognitive function and 5-HT system in rats after long term microwave exposure. Physiol Behav. 2015;140:236-46.

51. Vakalopoulos $C$. The EEG as an index of neuromodulator balance in memory and mental illness. Front Neurosci. 2014;8:63.

52. Thuröczy G, Kubinyi G, Bodo M, Bakos J, Szabo L. Simultaneous response of brain electrical activity (EEG) and cerebral circulation (REG) to microwave exposure in rats. Rev Environ Health. 1994:10:135-48.

53. Chizhenkova R. Slow potentials and spike unit activity of the cerebral cortex of rabbits exposed to microwaves. Bioelectromagnetics. 1988:9:337-45.

54. Nakatani-Enomoto S, Furubayashi T, Ushiyama A, Groiss SJ, Ueshima K, Sokejima S, et al. Effects of electromagnetic fields emitted from W-CDMA-like mobile phones on sleep in humans. Bioelectromagnetics. 2013;34:589-98.

55. Schmid MR, Murbach M, Lustenberger C, Maire M, Kuster N, Achermann P, et al. Sleep EEG alterations: effects of pulsed magnetic fields versus pulsemodulated radio frequency electromagnetic fields. J Sleep Res. 2012:21:620-9.

56. Vecchio F, Babiloni C, Lizio R, Fallani FV, Blinowska K, Verrienti G, et al. Resting state cortical EEG rhythms in Alzheimer's disease: toward EEG markers for clinical applications: a review. Suppl Clin Neurophysiol. 2012;62: 223-36.

57. Perentos A, Cuesta-Soto F, Canciamilla A, Vidal B, Pierno L, Losilla NS, et al. Using a ring resonator notch filter for optical carrier reduction and modulation depth enhancement in radio-over-fiber links. Phot J. 2013;5: 5500110.

58. Suhhova A, Bachmann M, Karai D, Lass J, Hinrikus H. Effect of microwave radiation on human EEG at two different levels of exposure. Bioelectromagnetics. 2013;34:264-74.

59. Othman H, Ammari M, Rtibi K, Bensaid N, Sakly M, Abdelmelek H. Postnatal development and behavior effects of in-utero exposure of rats to radiofrequency waves emitted from conventional WiFi devices. Environ Toxicol Pharmacol. 2017:52:239-47.

60. Othman H, Ammari M, Sakly M, Abdelmelek H. Effects of prenatal exposure to WIFI signal $(2.45 \mathrm{GHz})$ on postnatal development and behavior in rat: influence of maternal restraint. Behav Brain Res. 2017;326:291.

61. Zhang Y, Li Z, Gao Y. Effects of fetal microwave radiation exposure on offspring behavior in mice. J Radiat Res (Tokyo). 2015;56:261-8.

62. Qiao S, Peng R, Yan H, Gao Y, Wang C, Wang S, et al. Reduction of Phosphorylated Synapsin I (Ser-553) leads to spatial memory impairment by attenuating GABA release after microwave exposure in Wistar rats. PLoS One. 2014;9:e95503

63. Ning $\mathrm{W}$, Chiang $\mathrm{H}_{1}$ Y Yang $\mathrm{W}$. Effects of GSM $1800 \mathrm{MHz}$ on dendritic development of cultured hippocampal neurons. Acta Pharmacol Sin. 2007;28:1873-80.

64. Xu S, Ning W, Xu Z, Zhou S, Chiang H, Luo J. Chronic exposure to GSM 1800-MHz microwaves reduces excitatory synaptic activity in cultured hippocampal neurons. Neurosci Lett. 2006;398:253-7.

65. Wang $L, H u X$, Peng $R$. Influence of long-term microwave radiation on contents of amino acids and monoamines in urine of Wistar rats. Chin J Indus Hyg. 2010;28:445.

66. Myhrer T. Neurotransmitter systems involved in learning and memory in the rat: a meta-analysis based on studies of four behavioral tasks. Brain Res Rev. 2003:41:268-87.

67. Riedel G, Platt B, Micheau J. Glutamate receptor function in learning and memory. Behav Brain Res. 2003;140:1-47.

68. Wang L, Peng R, Hu X, Gao Y, Wang S, Zhao L, et al. Abnormality of synaptic vesicular associated proteins in cerebral cortex and hippocampus after microwave exposure. Synapse. 2009;63:1010-6.

69 Cull-Candy SG, Leszkiewicz DN. Role of distinct NMDA receptor subtypes at central synapses. Sci STKE. 2004;2004:1-9. 
70 Furukawa H, Singh SK, Mancusso R, Gouaux E. Subunit arrangement and function in NMDA receptors. Nature. 2005;438:185-92.

71 Ito K, Hirao A, Arai F, Takubo K, Matsuoka S, Miyamoto K, et al. Reactive oxygen species act through p38 MAPK to limit the lifespan of hematopoietic stem cells. Nat Med. 2006;12:446-51.

72 Wang $H$, Peng $R$, Zhao L, Wang S, Gao Y, Wang L, et al. The relationship between NMDA receptors and microwave induced learning and memory impairment: a long term observation on Wistar rats. Int J Radiat Biol. 2014:1-25.

73 Campisi A, Gulino M, Acquaviva R, Bellia P, Raciti G, Grasso R, et al. Reactive oxygen species levels and DNA fragmentation on astrocytes in primary culture after acute exposure to low intensity microwave electromagnetic field. Neurosci Lett. 2010:473:52-5.

74 Ozben T. Oxidative stress and apoptosis: impact on cancer therapy. J Pharm Sci. 2007:96:2181-96.

75 Dasdag S, Bilgin H, Akdag M, Celik H, Aksen F. Effect of long term mobile phone exposure on oxidative-antioxidative processes and nitric oxide in rats. Biotechnol Biotechnol Equip. 2008;22:992-7.

76 Shahin S, Banerjee S, Singh SP, Chaturvedi CM. 2.45 GHz Microwave Radiation Impairs Learning and Spatial Memory via Oxidative/Nitrosative Stress Induced p53-Dependent/Independent Hippocampal Apoptosis: Molecular Basis and Underlying Mechanism. Toxicol Sci. 2015;148:1-50.

77 Kumar M, Singh SP, Chaturvedi CM. Chronic nonmodulated microwave radiations in mice produce anxiety-like and depression-like behaviours and calcium- and NO-related biochemical changes in the brain. Exp Neurobiol. 2016;25:318-27.

78 Mack A, Georg T, Kreis P, Eickholt BJ. Defective actin dynamics in dendritic spines: cause or consequence of age-induced cognitive decline? Biol Chem. 2016;397:223-9.

79 Kayhan H, Esmekaya MA, Saglam AS, Tuysuz MZ, Canseven AG, Yagci AM, et al. Does MW radiation affect gene expression, apoptotic level, and cell cycle progression of human sh-sy5y neuroblastoma cells? Cell Biochem Biophys. 2016;74:99-107.

80 Joubert V, Bourthoumieu S, Leveque P, Yardin C. Apoptosis is induced by radiofrequency fields through the caspase-independent mitochondrial pathway in cortical neurons. Radiat Res. 2008;169:38-45.

81 Motawi TK, Darwish HA, Moustafa YM, Labib MM. Biochemical modifications and neuronal damage in brain of young and adult rats after long-term exposure to mobile phone radiations. Cell Biochem Biophys. 2014;70:845-55.

82 Dasdag S, Akdag MZ, Aksen F, Bashan M, Buyukbayram H. Does 900 MHZ GSM mobile phone exposure affect rat brain? Electromagn Biol Med. 2004; 23:201-14.

83 Fragopoulou AF, Samara A, Antonelou MH, Xanthopoulou A, Papadopoulou $A$, Vougas K, et al. Brain proteome response following whole body exposure of mice to mobile phone or wireless DECT base radiation. Electromagn Biol Med. 2012;31:250-74.

84 Verma RK, Sisodia R, Bhatia A. Radioprotective role of Amaranthus Gangeticus Linn.: a biochemical study on mouse brain. J Med Food. 2002;5: 189-95

85 Sharma A, Sisodia R, Bhatnagar D, Saxena VK. Spatial memory and learning performance and its relationship to protein synthesis of Swiss albino mice exposed to $10 \mathrm{GHz}$ microwaves. Int J Radiat Biol. 2014;90:29-35.

86 Calabrò E, Condello S, Currò M, Ferlazzo N, Caccamo D, Magazù S, et al. Modulation of HSP response in SH-SY5Y cells following exposure to microwaves of a mobile phone. World J Biol Chem. 2012;3:34-40.

87 Calabrò E, Magazù S. Inspections of mobile phone microwaves effects on proteins secondary structure by means of Fourier transform infrared spectroscopy. J Electromagnet Anal. 2010;2010

88 Koch C, Zador A. The function of dendritic spines: devices subserving biochemical rather than electrical computation. J Neurosci. 1993;13:413-22.

89 Harris KM. Structure, development, and plasticity of dendritic spines. Curr Opin Neurobiol. 1999;9:343-8.

90 Nimchinsky EA, Sabatini BL, Svoboda K. Structure and function of dendritic spines. Annu Rev Physiol. 2002;64:313-53.

91 Johnson OL, Ouimet CC. Protein synthesis is necessary for dendritic spine proliferation in adult brain slices. Brain Res. 2004;996:89-96.

92 Dasdag S, Akdag MZ, Kizil G, Kizil M, Cakir DU, Yokus B. Effect of $900 \mathrm{MHz}$ radio frequency radiation on beta amyloid protein, protein carbonyl, and malondialdehyde in the brain. Electromagn Biol Med. 2012;31:67-74.

$93 \mathrm{Im} \mathrm{HI}$, Kenny PJ. MicroRNAs in neuronal function and dysfunction. Trends Neurosci. 2012;35:325-34
94 Abe M, Bonini NM. MicroRNAs and neurodegeneration: role and impact. Trends Cell Biol. 2013;23:30-6.

95 Baer C, Claus R, Plass C. Genome-wide epigenetic regulation of miRNAs in cancer. Cancer Res. 2013;73:473-7.

96 Stahlhut Espinosa CE, Slack FJ. The role of microRNAs in cancer. Yale J Biol Med. 2006:79:131-40.

97 Dasdag S, Akdag MZ, Erdal ME, Erdal N, Ay Ol, Ay ME, et al. Long term and excessive use of $900 \mathrm{MHz}$ radiofrequency radiation alter microRNA expression in brain. Int J Radiat Biol. 2015;91:306-11.

98 Dasdag S, Akdag MZ, Erdal ME, Erdal N, Ay Ol, Ay ME, et al. Effects of 2.4 $\mathrm{GHz}$ radiofrequency radiation emitted from Wi-Fi equipment on microRNA expression in brain tissue. Int J Radiat Biol. 2015;91:555-61.

99 Zhao L, Sun C, Xiong L, Yang Y, Gao Y, Wang L, et al. MicroRNAs: novel mechanism involved in the pathogenesis of microwave exposure on rats' hippocampus. J Mol Neurosci. 2014;53:222-30.

100 Hassanshahi A, Shafeie SA, Fatemi I, Hassanshahi E, Allahtavakoli M, Shabani M, et al. The effect of Wi-Fi electromagnetic waves in unimodal and multimodal object recognition tasks in male rats. Neurol Sci. 2017;38:1069-76.

101 Megha K, Deshmukh PS, Banerjee BD, Tripathi AK, Ahmed R, Abegaonkar MP. Low intensity microwave radiation induced oxidative stress, inflammatory response and DNA damage in rat brain. Neurotoxicology. 2015;51:158-65

102 Belyaev IY, Koch CB, Terenius O, Roxström-Lindquist K, Malmgren LO, Sommer $H W$, et al. Exposure of rat brain to $915 \mathrm{MHz}$ GSM microwaves induces changes in gene expression but not double stranded DNA breaks or effects on chromatin conformation. Bioelectromagnetics. 2006;27:295-306.

103 Merola P, Marino C, Lovisolo G, Pinto R, Laconi C, Negroni A. Proliferation and apoptosis in a neuroblastoma cell line exposed to $900 \mathrm{MHz}$ modulated radiofrequency field. Bioelectromagnetics. 2006;27:164-71.

104 Qutob S, Chauhan V, Bellier P, Yauk C, Douglas G, Berndt L, et al. Microarray gene expression profiling of a human glioblastoma cell line exposed in vitro to a $1.9 \mathrm{GHz}$ pulse-modulated radiofrequency field. Radiat Res. 2006; 165:636-44

105 Wang LF, Tian DW, Li HJ, Gao YB, Wang CZ, Zhao L, et al. Identification of a novel rat nr2b subunit gene promoter region variant and its association with microwave-induced neuron impairment. Mol Neurobiol. 2016:53:2100-11.

106 Gibson GE, Jope R, Blass J. Decreased synthesis of acetylcholine accompanying impaired oxidation of pyruvic acid in rat brain minces. Biochem J. 1975;148:17-23.

107 Mosconi L, Tsui WH, Rusinek H, De Santi S, Li Y, Wang GJ, et al. Quantitation, regional vulnerability, and kinetic modeling of brain glucose metabolism in mild Alzheimer's disease. Eur J Nucl Med Mol Imaging. 2007:34:1467-79.

108 Nicholson RM, Kusne Y, Nowak LA, LaFerla FM, Reiman EM, Valla J. Regional cerebral glucose uptake in the 3xTG model of Alzheimer's disease highlights common regional vulnerability across $A D$ mouse models. Brain Res. 2010;1347:179-85.

109 Gage FH, Kelly P, Bjorklund A. Regional changes in brain glucose metabolism reflect cognitive impairments in aged rats. J Neuro. 1984;4:2856-65.

110 Choeiri C, Staines W, Miki T, Seino S, Messier C. Glucose transporter plasticity during memory processing. Neuroscience. 2005;130:591-600.

111 Kwon MS, Vorobyev V, Kännälä S, Laine M, Rinne JO, Toivonen T, et al. GSM mobile phone radiation suppresses brain glucose metabolism. J Cereb Blood Flow Metab. 2011;31:2293-301.

112 Durkin TP, Messier C, de Boer P, Westerink B. Raised glucose levels enhance scopolamine-induced acetylcholine overflow from the hippocampus: an in vivo microdialysis study in the rat. Behav Brain Res. 1992;49:181-8.

113 Ragozzino ME, Unick KE, Gold PE. Hippocampal acetylcholine release during memory testing in rats: augmentation by glucose. P Nat Acad. 1996;93:4693-8.

114 Messier C, Durkin T, Mrabet O, Destrade C. Memory-improving action of glucose: indirect evidence for a facilitation of hippocampal acetylcholine synthesis. Behav Brain Res. 1990;39:135-43.

115 Gold PE. Acetylcholine modulation of neural systems involved in learning and memory. Neurobiol Learn Mem. 2003;80:194-210.

116 Gold PE. Acetylcholine: cognitive and brain functions. Neurobiol Learn Mem. 2003;80:177

117 Krylova I, Dukhanin A, Il'in A, Kuznetsova EY, Balaeva N, Shimanovskii N, et al. Effect of microwave radiation on learning and memory. Bull Exp Biol Med. 1992:114:1620-2.

118 Wang L, Li X, Peng R, Gao Y, Zhao L, Wang S, et al. A metabolomic approach to screening urinary metabolites upon microwave exposure in monkeys. Mil Med Sci. 2011;35:369-78. 
119 Sanders AP, Joines WT. The effects of hyperthermia and hyperthermia plus microwaves on rat brain energy metabolism. Bioelectromagnetics. 1984;5: 63-70.

120 Zhao L, Peng RY, Gao YB, Wang SM, Wang LF, Dong J, et al. Mitochondria morphologic changes and metabolic effects of rat hippocampus after microwave irradiation. Chin J Radiol Med Prot. 2007;27:602-4.

121 Wang Q, Cao Z. Effect of microwave electromagnetic fields on activity of energy metabolism cytochrome oxidase in cerebral cortical neurons of postnatal rats. J Environ Health. 2005;22:329-31.

122 Ongwijitwat S, Wong-Riley MT. Is nuclear respiratory factor 2 a master transcriptional coordinator for all ten nuclear-encoded cytochrome $\mathrm{C}$ oxidase subunits in neurons? Gene. 2005;360:65-77.

123 Chandrasekaran K, Hatanpää K, Rapoport SI, Brady DR. Decreased expression of nuclear and mitochondrial DNA-encoded genes of oxidative phosphorylation in association neocortex in Alzheimer disease. Mol Brain Res. 1997:44:99-104.

124 Ellis CE, Murphy EJ, Mitchell DC, Golovko MY, Scaglia F, Barceló-Coblijn GC, et al. Mitochondrial lipid abnormality and electron transport chain impairment in mice lacking a-synuclein. Mol Cell Biol. 2005;25:10190-201.

125 Caubet R, Pedarros-Caubet F, Chu M, Freye E, de Belem RM, Moreau J, et al. A radio frequency electric current enhances antibiotic efficacy against bacterial biofilms. Antimicrob Agents Chemother. 2004:48:4662-4.

126 Kang D, Hamasaki N. Mitochondrial transcription factor a in the maintenance of mitochondrial DNA. Ann N Y Acad Sci. 2005:1042:101-8.

$127 \mathrm{Li} \mathrm{H}, \mathrm{Li}$ C. Apoptosis gene expression and their relationship to mtDNA mutation in tumor tissues of gynecologic oncology patients. Chin J Birth Health Hered. 2003;11:34-6.

128 Lu M, Zhu J, Qian C, Wang G, Nie J, Tong J. Biological effects of $2450 \mathrm{MHz}$ microwave combined with $y$-rays on rat cultured gliacytes. J Radiat Proc. 2010;3:46-50.

\section{Submit your next manuscript to BioMed Central and we will help you at every step:}

- We accept pre-submission inquiries

- Our selector tool helps you to find the most relevant journal

- We provide round the clock customer support

- Convenient online submission

- Thorough peer review

- Inclusion in PubMed and all major indexing services

- Maximum visibility for your research

Submit your manuscript at www.biomedcentral.com/submit

) Biomed Central 